Tropical Journal of Pharmaceutical Research May 2017; 16 (5): 1091-1095

ISSN: $1596-5996$ (print); 1596-9827 (electronic)

(C) Pharmacotherapy Group, Faculty of Pharmacy, University of Benin, Benin City, 300001 Nigeria.

All rights reserved.

Available online at http://www.tjpr.org

Original Research Article

http://dx.doi.org/10.4314/tjpr.v16i5.17

\title{
Effect of Alisma plantago-aquatica Linn extract on chronic prostatitis in rats
}

\author{
Xiao-ming Wang, Dong-dong Wang, Yu-zheng Wu, Peng-de Ma, Guang Sun \\ and Yong $\mathrm{Xu}^{*}$ \\ Department of Urology, Tianjin second Hospital of Tianjin Medical University, Tianjin Institute of Urology, Tianjin 300211, China
}

${ }^{*}$ For correspondence: Email: xuyong494@sina.com; Tel: +86 13001309410

Sent for review: 24 July 2016

Revised accepted: 10 April 2017

\begin{abstract}
Purpose: To study the effect of Alisma plantago-aquatica Linn. extract (APLE) on chronic prostatitis in rats.

Methods: Experimental chronic non-bacterial prostatitis (CNP) was induced in rats by injecting carrageenan into prostate. Rats in drug-treated groups were administered APLE or cernilton (positive control, i.e., reference standard) for 3 weeks while rats in normal and negative control groups were treated with saline at the same time. After treatment, prostate index (PI) and prostate-specific antigen (PSA) of all the rats were examined by enzyme-linked immunosorbent assay (ELISA). In addition, the relative inflammatory factors, tumor necrosis factor- $\alpha$ (TNF- $\alpha$ ), interleukin $1 \beta$ (IL-1 $\beta)$, cyclooxygenase-2 (COX-2), prostaglandin E2 (PEG2), transforming growth factor- $\beta 1$ (TGF- $\beta 1$ ) and connective tissue growth factor (CTGF) of the prostate tissues were measured by ELISA.

Results: A high dose of APLE (480 mg/kg) significantly decreased PI $(0.7 \pm 0.2 \mathrm{mg} / \mathrm{g})$ relative to reference group $(2.8 \pm 0.3 \mathrm{mg} / \mathrm{g}, p<0.01)$, and significantly decreased PSA level $(128.6 \pm 12.3 \mathrm{pg} / \mathrm{mL})$ relative to reference group $(321.3 \pm 16.4 \mathrm{pg} / \mathrm{mL}, p<0.01)$. Compared with reference group, TNF- $\alpha$ level

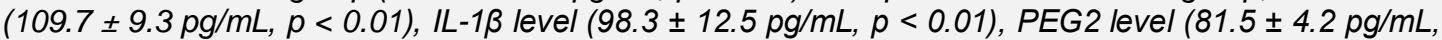
$p<0.01)$, COX-2 level $(10.5 \pm 2.6 \mathrm{pg} / \mathrm{mL}, p<0.01)$, TGF- $\beta 1$ level $(86.8 \pm 7.3 \mathrm{pg} / \mathrm{mL}, p<0.01)$ and CTGF level $(70.3 \pm 4.3 \mathrm{pg} / \mathrm{mL}, p<0.01)$ of prostate tissues of high-dose APLE group rats decreased significantly.

Conclusion: APLE shows significant anti-chronic prostatitis activity in rats. Further studies are, however, required to ascertain its therapeutic potentials in humans
\end{abstract}

Keywords: Alisma plantago-aquatica, Chronic prostatitis, Inflammation, Prostate index, Morphometric analysis, Interstitial fibrosis

Tropical Journal of Pharmaceutical Research is indexed by Science Citation Index (SciSearch), Scopus, International Pharmaceutical Abstract, Chemical Abstracts, Embase, Index Copernicus, EBSCO, African Index Medicus, JournalSeek, Journal Citation Reports/Science Edition, Directory of Open Access Journals (DOAJ), African Journal Online, Bioline International, Open-J-Gate and Pharmacy Abstracts

\section{INTRODUCTION}

Chronic prostatitis is characterized by a variety of symptoms, and has been shown to have a significant impact on quality of life [1,2]. While most typically associated with pain in the pelvic region, patients may have varying degrees of obstructive and/or irritating voiding symptoms, pain with ejaculation, sexual dysfunction, depression and/or psychosocial dysfunction that may be concomitant or related to the other symptoms. Chronic pelvic or genitourinary pain is a primary component of the condition and is typically present for at least three of the preceding 6 months [3]. As much as $10-15 \%$ of the male population may be affected at some point in their lives, and affects men of all ages. Prostatitis is responsible for up to 2 million outpatient clinic visits per year, including $8 \%$ of 
all male visits to a urologist and $1 \%$ of men presenting to primary care physicians [4]. Cernilton is one of the most widely used drugs for treating chronic non-bacterial prostatitis, but has not achieved significant curative effect in clinic.

At present, orthodox treatment of chronic prostatitis is not satisfactory, and a large number of patients are opting for therapy of traditional Chinese medicine. Herbal-based therapies are prevalent and popular in urological disease, more so in prostatic disorders. Examples include Chinese herbs, green tea extracts, saw palmetto and bee pollen, but unfortunately not all studies are adequately controlled [5-7].

The plant Alisma plantago-aquatica Linn., which is widely distributed in Southwest of China, is the main material of traditional Chinese medicine "Zexie". It was used as folk medicine for immune-modulation [8], anti-tumor [9] and antibacterial $[10,11]$. The aim of the present study was to evaluate the therapeutic effects of APLE against carrageenan-induced chronic nonbacterial prostatitis as well as explore its possible mechanism of action.

\section{EXPERIMENTAL}

\section{Materials}

Samples of Alisma plantago-aquatica Linn. were collected from Liuzhou City, Guangxi Province in China in May 2016. Taxonomic identification of the plant was performed by Professor Ping Wang of Tianjin Medical University, in China. A voucher specimen (no. APLE 201605002) was deposited in the herbarium of College of Pharmacy, Tianjin Medical University, China for future reference.

Alisma plantago-aquatica Linn was dried in an oven. APLE was obtained by steeping the dried Alisma plantago-aquatica Linn. in water at $60{ }^{\circ} \mathrm{C}$ three times, each for $1 \mathrm{~h}$ before first drying in a oven and then freeze-drying the last extract thus obtained. One gram powder was equivalent to about $1.7 \mathrm{~g}$ crude samples. The yield was 58.82 $\%$.

\section{Animals}

Eight weeks old male Wistar rats $(220-250 \mathrm{~g})$ were provided by the Experimental Animal Center of Tianjin Municipality (Certificate no. SYXK 2002-0006). The animals had free access to feed and water, and were allowed to acclimatize for at least one week before use. The rat experiment was approved by the Animal Care and Use Committee of Tianjin Medical University (approval ref no. 20100405) and was carried out in compliance with the Directive 2010/63/EU on the handling of animals used for scientific purposes [12].

\section{Animal groups}

The rats were randomly divided into six groups of ten rats in each: control group, reference group, positive drug group (cernilton $100 \mathrm{mg} / \mathrm{kg}$ ) as well as APLE groups, namely, 120, 240 and 480 $\mathrm{mg} / \mathrm{kg}$ doses. The drugs were dissolved in water, and administered using a $5 \mathrm{~mL}$ syringe with a 4$\mathrm{cm}$ long gavage needle through the mouth once daily for 3 weeks.

\section{Carrageenan-induced chronic non-bacterial prostatitis model (CNP)}

Chronic non-bacterial prostatitis were induced as previously described [13]. Prostates of rats in control group were injected with $0.1 \mathrm{~mL}$ saline by an injector, and the same volume of $1 \%$ carrageenan in rats of other groups. Seven days after preparing the model rats of chronic nonbacterial prostatitis, rats in APLE group, they were orally administered APLE, while rats in positive (reference standard) group were administered cernilton, both groups for 3 weeks. Rats of normal and negative control groups were administered saline at the same time.

\section{Measurement of prostatic index (PI) and prostate specific antigen (PSA)}

The prostatic index $(\mathrm{PI})$ of all rats was assessed as the ratio of prostate weight $(\mathrm{mg})$ to rat body weight $(\mathrm{g})$. A blood sample was taken from eye enucleation, and serum was separated at 3500 $\mathrm{r} / \mathrm{min}$ for $15 \mathrm{~min}$ and used for determination of prostate specific antigen (PSA) by ELISA kits (Nanjing Jiancheng Biological Technology Co Ltd, Najing, China).

\section{Biochemical assays}

After the rats were sacrificed by cervical dislocation, the pro-inflammatorycytokines TNF- $\alpha$ and IL-1 $\beta$ of prostate tissues of all rats were measured by commercial ELISA assay kits (Nanjing Jiancheng Biological Technology Co Ltd, Najing, China), according to manufacturer's instruction. The samples and standards were all run in duplicates and the data were then averaged. The results were expressed as $\mathrm{pg} / \mathrm{mL}$.

$\mathrm{PGE}_{2}, \quad \mathrm{COX}-2$, TGF- $\beta 1$ and CTGF were measured in prostate tissues using commercial ELISA kits (Shenzhen Xin-Bo-Sheng Biological Technology Co Ltd, China). All assays were 
performed in $10 \%$ prostate supernatant in accordance with manufacturer's instructions. The levels of $\mathrm{PGE}_{2}, \mathrm{COX}-2, \mathrm{TGF}-\beta 1$ and CTGF in prostate tissue are expressed in $\mathrm{pg} / \mathrm{mL}$.

\section{Statistical analysis}

Data are presented as mean \pm standard deviation (SD) and were analyzed statistically by one-way ANOVA followed by Tukey's multiple comparison using SPSS 16.0 software for Windows. Differences were considered statistically significant at $p<0.05$.

\section{RESULTS}

\section{Effect of APLE on PI and PSA}

The effects of oral administration of APLE on the levels of PI and PSA are summarized in Table 1. Compared with control group, PI and PSA level of reference group rats both increased significantly $(p<0.01)$. Compared with reference group, PI and PSA levels of high-dose of APLE decreased significantly $(p<0.01)$.

\section{Effect of APLE on TNF- $\alpha$ and IL-1 $\beta$}

As shown in Table 2, TNF-a level was 88.6 $\mathrm{pg} / \mathrm{mL}$ in control group. Carrageenan-treatment caused significant increase in the level of TNF- $\alpha$ compared with the control group $(p<0.01)$. TNFa level decreased when treated with $480 \mathrm{mg} / \mathrm{kg}$ of APLE compared to control group ( $p<0.01)$. The level of IL-1 $\beta$ was significantly increased in control group compared to control group $(p<$ $0.01)$. However, the IL-1 $\beta$ level was significantly decreased to 111.6 and $94.1 \mathrm{pg} / \mathrm{mL}$ at the dose of 240 and $480 \mathrm{mg} / \mathrm{kg}$ groups respectively ( $p<$ $0.01)$.

\section{Effect of APLE on PGE 2 , COX-2, TGF- $\beta 1$ and CTGF}

As shown in Table 3, the level of TGF- $\beta 1$ was $81.7 \mathrm{pg} / \mathrm{mL}$ in control group. Carrageenan caused significant increase in the level of TGF$\beta 1$ in reference group $(p<0.01)$. After rats was treated with APLE for three weeks, the level of TGF- $\beta 1$ was dose-dependently decreased ( $p<$ 0.01). Similarly, the level of CTGF was elevated in model group when compared with the control group $(p<0.01)$. However, in APLE treated group, the elevation was suppressed compared with the reference group $(p<0.01)$.

COX-2 level was increased significantly compared to control group $(p<0.01)$. However, treatment of APLE decreased the level of COX-2 $(p<0.01)$. The level of $\mathrm{PEG}_{2}$ was increased in negative control group compared to control group $(p<0.01)$. Oral treatment of APLE at 240 and $480 \mathrm{mg} / \mathrm{kg}$ resulted in significant decrease of $\mathrm{PEG}_{2}$ content when compared with negative control group $(p<0.01)$.

Table 1: Effect of APLE on PI and PSA levels

\begin{tabular}{lccc}
\hline Group & Dose $(\mathbf{m g} / \mathbf{k g})$ & PI $(\mathbf{m g} / \mathbf{g})$ & PSA $(\mathbf{p g} / \mathbf{m l})$ \\
\hline Control & - & $0.7 \pm 0.2^{* *}$ & $106.4 \pm 11.8^{* *}$ \\
Negative control & - & $2.8 \pm 0.3$ & $321.3 \pm 16.4$ \\
Cernilton & 100 & $1.6 \pm 0.4$ & $141.7 \pm 13.5^{* *}$ \\
APLE-L & 120 & $1.7 \pm 0.3$ & $268.5 \pm 28.3$ \\
APLE-M & 240 & $1.5 \pm 0.4^{*}$ & $159.2 \pm 17.5^{*}$ \\
APLE-H & 480 & $0.8 \pm 0.3^{* *}$ & $128.6 \pm 12.3^{* *}$ \\
${ }^{*}<0.05, \quad p<0.01$ vs. negative control group; values are mean \pm SD $(\mathrm{n}=$ \\
10); APLE-L: low-dose of APLE; APLE-M: middle-dose of APLE; APLE-H: \\
high-dose of APLE
\end{tabular}

Table 2: Effect of APLE on TNF- $\alpha$ and IL-1 $1 \beta$ levels

\begin{tabular}{|c|c|c|c|}
\hline Group & Dose (mg/kg) & TNF- $\alpha(\mathrm{pg} / \mathrm{ml})$ & IL-1 $\beta$ (pg/mL) \\
\hline Control & - & $88.6 \pm 7.7^{* *}$ & $84.5 \pm 6.2^{* *}$ \\
\hline Negative control & - & $169.4 \pm 13.5$ & $154.2 \pm 9.8$ \\
\hline Cernilton & 100 & $128.3 \pm 9.5^{* *}$ & $127.2 \pm 11.4^{\star *}$ \\
\hline APLE-L & 120 & $146.6 \pm 12.4$ & $137.3 \pm 12.2$ \\
\hline APLE-M & 240 & $134.1 \pm 9.3^{*}$ & $122.5 \pm 9.2^{\star \star}$ \\
\hline APLE-H & 480 & $109.7 \pm 9.3^{\star \star}$ & $98.3 \pm 12.5^{*}$ \\
\hline
\end{tabular}


Table 3: Effect of APLE on PGE 2 , COX-2, TGF- $\beta 1$ and CTGF levels

\begin{tabular}{|c|c|c|c|c|c|}
\hline Group & $\begin{array}{c}\text { Dose } \\
(\mathrm{mg} / \mathrm{kg})\end{array}$ & $\begin{array}{c}\mathrm{PGE}_{2} \\
(\mathrm{pg} / \mathrm{mL})\end{array}$ & $\begin{array}{c}\text { COX-2 } \\
\text { (pg/mL) }\end{array}$ & $\begin{array}{l}\text { TGF- } \beta 1 \\
\text { (pg/mL) }\end{array}$ & $\begin{array}{c}\text { CTGF } \\
\text { (pg/mL) }\end{array}$ \\
\hline Control & & $53.5 \pm 3.8$ & $12.3 \pm 1.8$ & $79.4 \pm 4.2$ & $71.6 \pm 4.5^{* \prime}$ \\
\hline Negative control & & $124.1 \pm 4.9$ & $38.6 \pm 2.9$ & $129.6 \pm 12.1$ & $121.4 \pm 5.8$ \\
\hline Cernilton & 100 & $76.3 \pm 4.2^{* x}$ & $18.2 \pm 2.6^{\pi}$ & $115.3 \pm 8.7^{*}$ & $96.4 \pm 4.4^{\pi \pi}$ \\
\hline APLE-L & 120 & $117.2 \pm 5.1$ & $22.3 \pm 4.7$ & $123.6 \pm 8.4$ & $112.2 \pm 6.2$ \\
\hline APLE-M & 240 & $90.2 \pm 5.4$ & $16.5 \pm 3.7$ & $111.4 \pm 7.2^{n}$ & $92.5 \pm 5.8^{n}$ \\
\hline APLE-H & 480 & $81.5 \pm 4.2$ & $10.5 \pm 2.6$ & $86.8 \pm 7.3^{n}$ & $70.3 \pm 4.3^{n}$ \\
\hline
\end{tabular}

\section{DISCUSSION}

Antibiotics are largely ineffective in the treatment of CNP as the chronic nature of the syndrome is thought not to be completely attributable to an ongoing active or latent bacterial infection. Despite this, up to almost $80 \%$ of CNP patients receive antibiotics as treatment at some point during their disease course, more than 7 times that of non-CNP patients, and many receive multiple rounds of antibiotics despite lack of efficacy [14]. It is well accepted that the progression of CNP is related to the complex network of cytokines, including IL- $1 \beta$ and TNF- $\alpha$ $[14,15]$. IL-1 $\beta$ is a pro-inflammatory cytokine that induces the production of other inflammatory mediators involved in cellular recruitment, fever, acute phase protein release, increase of vascular permeability, and hyperalgesia [16]. TNF- $\alpha$, a pleiotropic pro-inflammatory cytokine, is rapidly produced by macrophages in response to tissue damage [17]. Previous studies have shown that activation of transcription factor NF-KB by TNF- $\alpha$ is one of the myriad actions of TNF- $\alpha$ that cause genes to generate potentially cell damaging oxidative enzymes, as well as further release of TNF- $\alpha, \quad I L-1 \beta$ and other pro-inflammatory cytokines [18-20]. Cytokine based therapies have been found useful in preventing progression of chronic prostatitis [21].

In the present study, the levels of TNF- $\alpha$ and IL$1 \beta$ were increased in model group rats, whereas on treatment with APLE at 240 or $480 \mathrm{mg} / \mathrm{kg}$, there was a significant decrease in the cytokine levels. APLE suppressed the release of proinflammatory mediators due to its antiinflammatory activities. In this study, the levels of COX-2 and $\mathrm{PEG}_{2}$ in the model group, were enhanced. However, the increased levels of COX-2 and $P E G_{2}$ were reversed in treatment group of APLE. In addition, it was found that APLE at the dose of $480 \mathrm{mg} / \mathrm{kg}$ significantly decreased $C O X-2$ and $P E G_{2}$ levels. Therefore, the anti-CNP effect of APLE may be related to its anti-inflammatory properties.

TGF- $\beta$ is the most extensively studied molecule in fibrosis and stimulates the production of reactive oxygen species (ROS) in various types of cells. Whereas ROS activates TGF- $\beta$ and mediate many of the fibrogenic effects of TGF- $\beta$ [22]. TGF- $\beta 1$ is known to induce fibroblast differentiation into myofibroblast/smooth muscle cell in the human prostate [23]. In addition, other evidence suggests that pro-fibrotic effects of TGF- $\beta$ may be partly mediated by CTGF [24]. As another potent profibrotic factor, CTGF is implicated in fibroblast proliferation, cellular adhesion, angiogenesis, and extracellular matrix (ECM) synthesis [25].

\section{CONCLUSION}

The findings of this study reveal that APLE has anti-inflammatory activities and exerts antichronic prostatitis effect in rats. However, further investigations are required determines its therapeutic action in humans.

\section{DECLARATIONS}

\section{Acknowledgement}

The authors are grateful to Professor Ping Wang of Tianjin Medical University for support in this study.

\section{Conflict of Interest}

No conflict of interest associated with this work.

\section{Contribution of Authors}

The authors declare that this work was done by the authors named in this article and all liabilities pertaining to claims relating to the content of this article will be borne by them.

\section{Open Access}

This is an Open Access article that uses a funding model which does not charge readers or their institutions for access and distributed under the terms of the Creative Commons Attribution License (http://creativecommons.org/licenses/by/ 
4.0) and the Budapest Open Access Initiative (http://www.budapestopenaccessinitiative.org/rea d), which permit unrestricted use, distribution, and reproduction in any medium, provided the original work is properly credited.

\section{REFERENCES}

1. Murphy AB, Macejko A, Taylor A. Chronic prostatitis management strategies. Drugs 2009; 69: 71-84.

2. Weidner W, Brunner H, Krause W. Quantitative culture of ureaplasma urealyticum in patients with chronic prostatitis or prostatosis. J Urol 1980; 124: 622-625.

3. Schaeffer AJ. Prostatitis: US perspective. Int. J. Ant. Agents 1999; 11: 205-211.

4. Krieger JN, Nyberg Jr L, Nickel JC. NIH consensus definition and classification of prostatitis. JAMA: J Am Med Assoc 1999; 282: 236-237.

5. Shoskes DA, Manickam K. Herbal and complementary medicine in chronic prostatitis. World J Urol 2003; 21: 109-113.

6. Lee YS, Han CH, Kang SH, Lee SJ, Kim SW, Shin OR. Synergistic effect between catechin and ciprofloxacin on chronic bacterial prostatitis rat model. Int J Urol 2005; 12: 383-389.

7. Choi YS, Cho $\mathrm{YH}$, Han $\mathrm{CH}$. Synergistic effect between ginsenoside or Urovaxom® with ciprofloxacin on chronic bacterial prostatitis rat model. Korean J Urol 2007; 48: 849-857.

8. Krieger JN, Nyberg L, Jr, Nickel JC. NIH consensus definition and classification of prostatitis. JAMA 1999; 282:236-7.

9. Jung HW, Jin GZ, Kim SY. Neuroprotective effect of methanol extract of Phellodendri Cortex against 1methyl-4-phenylpyridinium (MPP+)-induced apoptosis in PC-12 cells. Cell Biology International 2009; 33: 957963.

10. Poggio C, Trovati F, Ceci M, Chiesa M, Colombo M, Pietrocola G. Biological and antibacterial properties of a new silver fiber post: In vitro evaluation. J Clin Exp Dent. 2017; 9: e387-e393.

11. Xian YF, Mao QQ. Comparison on the anti-inflammatory effect of Cortex Phellodendri Chinensis and Cortex Phellodendri Amurensis in 12-O-tetradecanoyl-phorbol13-acetate-induced ear edema in mice. Journal of Ethnopharmacology 2011; 137: 1425-1430.

12. European Commission [homepage on the internet]. Directive 2010/63/EU on the protection of animals used for scientific purposes [cited 2013 Jan 16]. Available from:http://ec.europa.eu/environment/chemicals/lab_ani mals/legislation_en.htm.

13. Chen RZ, Cui L, Guo, YJ, Rong, YM, Lu, XH, Sun, $M Y$, Zhang, L, Tian, JK. In vivo study of four preparative extracts of Clematis terniflora DC. for antinociceptive activity and anti-inflammatory activity in rat model of carrageenan-induced chronic non-bacterial prostatitis. J. Ethnopharmacol 2011b; 134: 1018-1023.

14. Nadler RB, Koch AE, Calhoun EA, Campbell PL, Pruden $D L$, Bennett CL, Yarnold PR, Schaeffer AJ. IL-1beta and TNF-alpha in prostatic secretions are indicators in the evaluation of men with chronic prostatitis. J Urol 2000; 164: 214-218.

15. Tsunemori $H$, Sugimoto $M$, Xia Z, Taoka R, Oka $M$, Kakehi $Y$. Effect of the phytotherapeutic agent Eviprostat on inflammatory changes and cytokine production in a rat model of nonbacterial prostatitis. Urol 2011; 77: e1515.

16. Shoskes DA, Hakim L, Ghoniem G, et al. Long-term results of multimodal therapy for chronic prostatitis/chronic pelvic pain syndrome. J Urol 2003; 169: 1406-10.

17. Beutler, B, Cerami, A. The biology of cachectin/TNF-a primary mediator of the host response. Annu Rev Immunol 1989; 7: 625-655.

18. Tahir $M$, Rehman $M U$, Lateef $A$, Khan R, Khan $A Q$, Qamar W, Ali F, O'Hamiza O, Sultana S. Diosmin protects against ethanol-induced hepatic injury via alleviation of inflammation and regulation of TNF-alpha and NF-kappa B activation. Alcohol 2013; 47: 131-139.

19. Xu H, He Y, Yang X, Liang L, Zhan Z, Ye Y, Yang X, Lian $F$, Sun L. Anti-malarial agent artesunate inhibits TNFalpha-induced production of proinflammatory cytokines via inhibition of NF-kappaB and PI3 kinase/Akt signal pathway in human rheumatoid arthritis fibroblast-like synoviocytes. Rheumatology (Oxford) 2007; 46: 920926.

20. Jiang CY, Wang W, Tang JX, Yuan ZR. The adipocytokine resistin stimulates the production of proinflammatory cytokines TNF- $\alpha$ and IL- 6 in pancreatic acinar cells via NF-KB activation. J Endocrinol Invest 2013; 36: 986-992.

21. Lu BY, Cai HF, Huang, WS, Wu XQ, Luo YX, Liu L, Zhang, $Y$. Protective effect of bamboo shoot oil on experimental nonbacterial prostatitis in rats. Food. Chem. 2011; 124: 1017-1023.

22. Liu RM, Gaston KA. Oxidative stress and glutathione in TGF-beta-mediated fibrogenesis. Free. Radic. Biol. Med. 2010; 48: 1-15.

23. Untergasser, G, Gander, R, Lilg, C, Lepperdinger, G, Plas, E, Berger, P. Profiling molecular targets of TGFbeta1 in prostate fibroblast-to- myofibroblast transdifferentiation. Mech. Ageing. Dev. 2005; 126: 5969.

24. Shoskes DA, Nickel JC, Dolinga $R$, et al. Clinical phenotyping of patients with chronic prostatitis/chronic pelvic pain syndrome and correlation with symptom severity. Urology 2009; 73: 538-42.

25. Nickel JC, Downey J, Ardern D. Failure of a monotherapy strategy for difficult chronic prostatitis/chronic pelvic pain syndrome. J Urol 2004; 172: 551-554. 